\title{
Effect of Biotic and Abiotic Elicitors in Inducing Resistance against Cowpea Rust
}

\author{
Suryakanth $^{1}$, Venkatesh ${ }^{1}$, N. S. Pankaja ${ }^{1^{*}}$, N. Umashankar Kumar ${ }^{2}$, \\ J. Mahadeva ${ }^{3}$ and G. Sugeetha ${ }^{4}$
}

${ }^{1}$ Department of Plant Pathology, College of Agriculture, V. C. Farm, Mandya, India

${ }^{2}$ Department of Plant Pathology, College of Agriculture, Hassan, India

${ }^{3}$ Department of Forestry and Environmental Sciences, College of Agriculture,

V. C. Farm, Mandya, India

${ }^{4}$ Department of Agricultural Entomology, College of Agriculture, V. C. Farm, Mandya, India

*Corresponding author

\section{A B S T R A C T}

Keywords

Uredospores, Induced Resistance, Elicitors, Salicylic acid, Jasmonicacid, Trichoderma viridae,

Pseudomonas fluorescence

\section{Article Info}

\section{Accepted:}

24 October 2020

Available Online:

10 November 2020
Cowpea is important multipurpose crop which is used for the purpose of food, feed, forage, catch crop, green manuring and cover crop. The crop is prone to rust disease which causes severe yield loss. Hence to manage the disease chemicals which are expensive and hazardous are usually used by the farmers. Alternately a different strategy to manage the same was experimented with the use of elicitors which are compounds which activate chemical defence in plants and this induced defence response in susceptible variety C-152 was examined. The compounds like Salicylic acid (SA), Jasmonic Acid (JA), biocontrol agents viz., Trichoderma viridae, Pseudomonas fluorescence were used as elicitors. All elicitors were found effective in inducing resistance against rust disease by accelerating the enzyme activities like peroxidase, phenylalanine ammonia lyase and $\beta 1$, 3-glucanase activity. This was higher in abiotic elicitorsthan the biotic elicitors. The highest enzyme activity of phenylalanine ammonia lyase was recorded in foliar spray of $1 \mathrm{mM}$ salicylic acid at 50 DAS followed by uredospores suspension after 2 days whereas, highest peroxidase and $\beta 1,3$-glucanase activity was recorded in foliar spray of $0.5 \mathrm{mM}$ Jasmonic acid spray at 50 DAS followed by uredospore suspension after 2 days. Hence these elicitors could be used as alternative to chemical pesticides, an important component of organic farming and integrated disease management.

\section{Introduction}

Cowpea (Vigna unguiculata L.) is a multipurpose crop. In India, the crop is cultivated with a total area of 654 lakh hectares, and production of 599 lakh tonnes and a productivity of $916 \mathrm{~kg} \mathrm{ha}^{-1}$ (Joshi et al.,
2018). In Karnataka, the crop is grown in an area of 0.84 lakh hectares with a production of 0.25 lakh tonnes with low productivity 360 $\mathrm{kg} \mathrm{ha}{ }^{-1}$ as compared to the national productivity of $567 \mathrm{~kg} \mathrm{ha}^{-1}$ (Prabhamani et al., 2018). The overall grain yield of cowpea in the present traditional systems is low due to 
several biotic and abiotic factors (Singh and Singh, 1997).

The abiotic factors that cause yield reduction include drought, temperature extremes, excessive moisture, late maturity, acidity and stress. In India, a loss due to diseases is $20 \%$ and an insect pest is $25 \%$, Abiotic stresses reduce an average yield of crops by upto $50 \%$ (Verma and Deepthi, 2016).Among the biotic factors the crop is affected by number of fungal, bacterial, viral and nematode diseases. Among them, rust disease caused by a fungus Uromyces phaseoli var. vignae (Barclay) Arth. is one of the most important diseases that cause huge economic loss. To manage the disease there are number of strategies viz., cultural, physical, mechanical and chemical. Among them, chemical management stands as one of the important means because they are quick in action. Although fungicide can control the disease but increases the cost of production. The better understanding of plant signalling pathways has led to the discovery of natural and synthetic compounds called elicitors that induce defense responses in plants as induced by the pathogen infection. These compounds act as signal molecules at low concentrations, providing information for the plant to trigger defense.

Elicitors are the chemicals (or) bio-factors from various sources that can trigger physiological and morphological responses and also phytoalexin accumulation in the target plants and organisms. Originally elicitor was used for molecules capable of inducing the production of phytoalexins, but it is now commonly used for compounds stimulating any type of plant defense (Thakur and Sohal, 2013). Synthetic elicitors are small drug-like molecules that induce plant defense responses, but are distinct from known natural elicitors of plant immunity. Some synthetic elicitors are Polyamines, Salicylic acid, Benzothiadiazole, Jasmonic acid, Chitosan,
Brassinosteroids, Tricontinol, 2,6dichloroisonicotinic acid, Probenazole, Isotianil, Sulfanilamide, Clopamide, Butamide (Bektas and Euglem, 2015). While some of the biotic elicitors are enzymes like cellulase, pectinase and biocontrol agents includes Trichoderma viridae, Pseudomonas flourescense etc (Dixon, 2001). As elicitors can protect crops from diseases, may also serve as promising alternatives to conventional chemical pesticides, which often are harmful and has ill effects on the environment and non-target pests.

\section{Materials and Methods}

The analysis was carried out in Department of Plant Pathology, College of Agriculture, V. C. Farm, Mandya. To identify and to know the role of like Salicylic acid (SA), Jasmonic acid (JA), Trichoderma viridae, Pseudomonas fluorescence in eliciting the resistance against the pathogen an experiment was taken under greenhouse conditions. Ten treatments were taken up and replicated thrice under completely randomized design (CRD). The pots were filled with a 1:2:1 ratio of sand, soil and compost respectively. The susceptible cowpea variety C-152 was used for study. The treatments (Table 1) were imposed on the plants at 50 DAS. The leaf samples were collected before spraying and after spraying at 51, 53 and 55 DAS for analyzing the enzyme activity viz., peroxidase by using spectrophotometer method as described by Hartee (1955) and phenyl ammonia lyase activity by using Ross and Senderoff (1992) method and $\beta-1,3$-glucanase activity was estimated using the method given by Rakshit et al., (2000).

\section{Results and Discussion}

The peroxidase, phenylalanine ammonia lyase and $\beta 1,3-$ glucanaseactivity was recorded at 51, 53 and 55 DAS in different treatments. 


\section{Peroxidase activity}

The peroxidase activity was recorded at 51 , 53 and 55 DAS in different treatments. At 51 DAS the highest enzyme activity of $1.349 \Delta$ Abs $\min ^{-1} \mathrm{~g}^{-1}$ was recorded in T8 followed by T2 (1.251 $\Delta$ Abs $\left.\min ^{-1} \mathrm{~g}^{-1}\right)$, and T7 (1.237 $\Delta$ Abs $\left.\min ^{-1} \mathrm{~g}^{-1}\right)$ and there was a significant difference among them. However, the enzyme activity in T1 (1.076 $\Delta$ Abs $\left.\min ^{-1} \mathrm{~g}^{-1}\right)$ and T6 (1.007 $\left.\Delta \mathrm{Abs} \mathrm{min}^{-1} \mathrm{~g}^{-1}\right)$ were on par with each other. The lowest enzyme activity of 0.640 was recorded in T10 followed by T3 $(0.827 \Delta$ Abs $\left.\min ^{-1} \mathrm{~g}^{-1}\right)$ and T5 (0.890 $\Delta$ Abs $\left.\min ^{-1} \mathrm{~g}^{-1}\right)$ and there was a significant difference among them (Table 1).

The highest enzyme activity of $1.551 \Delta$ Abs $\min ^{-1} \mathrm{~g}^{-1}$ was recorded in T8 at $53 \mathrm{DAS}$, followed by T2 $\left(1.437 \Delta \mathrm{Abs} \mathrm{min}^{-1} \mathrm{~g}^{-1}\right)$ and T7 (1.379 $\Delta$ Abs $\left.\min ^{-1} \mathrm{~g}^{-1}\right)$ and T1 (1.298 $\Delta$ Abs $\min ^{-1} \mathrm{~g}^{-1}$ ) and there was a significant difference among them. However, the lowest enzyme activity was recorded in T10 $(0.733 \Delta$ Abs $\left.\min ^{-1} \mathrm{~g}^{-1}\right)$ followed by T3 (0.905 $\Delta$ Abs $\left.\min ^{-1} \mathrm{~g}^{-1}\right)$ and T9 (1.041 $\Delta$ Abs $\left.\min ^{-1} \mathrm{~g}^{-1}\right)$ and there was a significant difference among the treatment.

Further, at 55 DAS the highest peroxidase activity was recorded in T8 (1.753 $\Delta$ Abs $\left.\min ^{-1} \mathrm{~g}^{-1}\right)$ followed by T2 (1.699 $\Delta$ Abs $\min ^{-1}$ $\mathrm{g}^{-1}$ ) and in T7 (1.523 $\Delta$ Abs $\min ^{-1} \mathrm{~g}^{-1}$ ). Whereas, the lowest enzyme activity of 0.867 $\triangle$ Abs min $^{-1} \mathrm{~g}^{-1}$ was recorded in T10 followed by T3 $\left(1.034 \Delta\right.$ Abs $\left.\min ^{-1} \mathrm{~g}^{-1}\right)$ and T4 (1.100 $\Delta$ Abs $\left.\min ^{-1} \mathrm{~g}^{-1}\right)$ and there was a significant difference among the treatments.

Thus the above results revealed that the peroxidase enzyme activity in all the treatments were significantly high than the control during all the observations recorded (51, 53 and 55 DAS). Further, among the ten treatments the highest enzyme activity was recorded (1.753 $\Delta$ Abs $\left.\min ^{-1} \mathrm{~g}^{-1}\right)$ with foliar spray of $0.5 \mathrm{mM} \mathrm{JA}$ followed by uredospore suspension after 2 days (T8), followed by $1.699 \Delta \mathrm{Abs} \mathrm{min}^{-1} \mathrm{~g}^{-1}$ in foliar spray of SA at $1 \mathrm{mM}$ followed by uredospore suspension after 2 days (T2)and there was significant difference among them).

\section{Phenylalanine Ammonia Lyase (PAL) Activity}

(The phenylalanine ammonia lyase (PAL) enzyme activity was recorded at 51, 53 and 55 DAS. At 51 DAS the highest enzyme activity of $124 \mu \mathrm{mol}$ of trans cinnamic acid $\mathrm{min}^{-1} \mathrm{~g}^{-1}$ was recorded in T2 followed by T1 $(121 \mu \mathrm{mol}$ of trans cinnamic acid $\min ^{-1} \mathrm{~g}^{-1}$ ) and T8 (118 $\mu$ mol of trans cinnamic acid $\min ^{-1} \mathrm{~g}^{-1}$ ), which were on par with each other. The lowest enzyme activity was noticed in T10 $(81 \mu \mathrm{mol}$ of trans cinnamic acid $\min ^{-1} \mathrm{~g}^{-1}$ ) followed by T9 $\left(88 \mu\right.$ mol of trans cinnamic acid $\left.\min ^{-1} \mathrm{~g}^{-1}\right)$ and T5 $\left(95 \mu \mathrm{mol}\right.$ of trans cinnamic acid $\mathrm{min}^{-1}$ $\mathrm{g}^{-1}$ ) and there was a significant difference among them (Table 2).

Further, at 53 DAS the highest enzyme activity of $127 \mu \mathrm{mol}$ of trans cinnamic acid $\min ^{-1} \mathrm{~g}^{-1}$ was recorded in $\mathrm{T} 2$ followed by treatment $\mathrm{T} 1 \quad(122 \mu \mathrm{mol}$ of trans cinnamic acid $\left.\min ^{-1} \mathrm{~g}^{-1}\right)$ and T8 (121 $\mu \mathrm{mol}$ of trans cinnamic acid $\min ^{-1} \mathrm{~g}^{-1}$ ) and were on par with each other. The lowest enzyme activity was recorded in T10 $(82 \mu \mathrm{mol}$ of trans cinnamic acid $\left.\min ^{-1} \mathrm{~g}^{-1}\right)$ followed by T9 $(90 \mu \mathrm{mol}$ of trans cinnamic acid $\left.\min ^{-1} \mathrm{~g}^{-1}\right)$ and T5 $(96 \mu \mathrm{mol}$ of trans cinnamic acid $\min ^{-1} \mathrm{~g}^{-1}$ ) and there was a significant difference among them.

However, the highest enzyme activity was recorded in T2 $(130 \mu \mathrm{mol}$ of trans cinnamic acid $\min ^{-1} \mathrm{~g}^{-1}$ ) at 55 DAS, followed by T1 (125 $\mu$ mol of trans cinnamic acid $\min ^{-1} \mathrm{~g}^{-1}$ ) and T8 $(124 \mu \mathrm{mol}$ of trans cinnamic acid $\min ^{-1} \mathrm{~g}^{-1}$ ) which were on par with each other. Whereas, the lowest enzyme activity of 83 $\mu$ mol of trans cinnamic acid $\min ^{-1} \mathrm{~g}^{-1}$ was 
recorded T10 followed by T9 $(91 \mu \mathrm{mol}$ of trans cinnamic acid $\min ^{-1} \mathrm{~g}^{-1}$ ) and $\mathrm{T} 5$ (97 $\mu$ mol of trans cinnamic acid $\min ^{-1} \mathrm{~g}^{-1}$ ) and there was a significant difference among them.

The above results indicated that the PAL activity in all the treatments were significantly high than the control during all the observations recorded $(51,53$ and 55 DAS). Further, among the ten treatments highest PAL activity was recorded with foliar spray of $1 \mathrm{mM}$ salicylic acid followed by uredospore suspension after 2 days (T2) (130 $\mu$ mol of trans cinnamic acid $\min ^{-1} \mathrm{~g}^{-1}$ ), followed by foliar spray of $1 \mathrm{mM}$ salicylic acid at 50 DAS (T1) $(125 \mu \mathrm{mol}$ of trans cinnamic acid $\min ^{-1} \mathrm{~g}^{-1}$ ) which were significantly difference with each other.

The least enzyme activity of $124 \mu \mathrm{mol}$ of trans cinnamic acid $\min ^{-1} \mathrm{~g}^{-1}$ was recorded in control (T10) followed by $91 \mu \mathrm{mol}$ of trans cinnamic acid $\min ^{-1} \mathrm{~g}^{-1}$ with spray of uredospore suspension).

Table.1 Effect of different elicitors on peroxidase enzyme activity in the cowpea leaves

\begin{tabular}{|c|c|c|c|c|}
\hline \multirow[t]{2}{*}{ Treatments } & \multirow[t]{2}{*}{ Treatment details } & \multicolumn{3}{|c|}{$\begin{array}{l}\text { Peroxidase activity } \\
\left(\Delta \text { Abs } \min ^{-1} \mathrm{~g}^{-1}\right)\end{array}$} \\
\hline & & 51 DAS & 53 DAS & 55 DAS \\
\hline T1 & $\begin{array}{l}\text { Salicylic acid is sprayed at } 1 \mathrm{mM} \\
\text { concentration at } 50 \text { DAS }\end{array}$ & 1.076 & 1.298 & 1.493 \\
\hline T2 & $\begin{array}{l}\text { Foliar spray of } 1 \mathrm{mM} \text { salicylic acid at } 50 \\
\text { DAS followed by uredospores } \\
\text { suspension after } 2 \text { days }\end{array}$ & 1.251 & 1.437 & 1.699 \\
\hline T3 & $\begin{array}{l}\text { Trichoderma viride } 0.2 \% \text { is sprayed at } 50 \\
\text { DAS }\end{array}$ & 0.827 & 0.905 & 1.034 \\
\hline T4 & $\begin{array}{l}\text { Foliar spray of } 0.2 \% \text { Trichoderma viride } \\
\text { spray at 50 DAS followed by } \\
\text { uredospores suspension after } 2 \text { days }\end{array}$ & 0.927 & 1.005 & 1.100 \\
\hline T5 & $\begin{array}{l}\text { Pseudomonas fluorescence } 0.1 \% \text { is } \\
\text { sprayed at } 50 \text { DAS }\end{array}$ & 0.890 & 1.078 & 1.168 \\
\hline T6 & $\begin{array}{l}\text { Foliar spray of } 0.1 \% \text { Pseudomonas } \\
\text { fluorescence spray at } 50 \text { DAS followed } \\
\text { by uredospores suspension after } 2 \text { days }\end{array}$ & 1.007 & 1.180 & 1.248 \\
\hline T7 & Jasmonic acid $0.5 \mathrm{mM}$ spray at 50 DAS & 1.237 & 1.379 & 1.523 \\
\hline T8 & $\begin{array}{l}\text { Foliar spray of } 0.5 \mathrm{mM} \text { Jasmonic acid } \\
\text { spray at } 50 \text { DAS followed by uredospore } \\
\text { suspension after } 2 \text { days }\end{array}$ & 1.349 & 1.551 & 1.753 \\
\hline T9 & $\begin{array}{l}\text { Uredospore suspension sprayed at } 50 \\
\text { DAS }\end{array}$ & 0.901 & 1.041 & 1.127 \\
\hline T10 & Control & 0.640 & 0.733 & 0.867 \\
\hline $\mathbf{F}$ & & $* *$ & $* *$ & ** \\
\hline S.Em \pm & & 0.0134 & 0.0235 & 0.0240 \\
\hline CD@1\% & & 0.0537 & 0.0947 & 0.0967 \\
\hline
\end{tabular}

DAS- Days After Sowing

**- significant 
Table.2 Role of elicitors on phenylalanine ammonia lyase (PAL) activity in the cowpea leaves

\begin{tabular}{|c|c|c|c|c|}
\hline \multirow[t]{2}{*}{ Treatments } & \multirow[t]{2}{*}{ Treatment details } & \multicolumn{3}{|c|}{$\begin{array}{l}\text { PAL ( } \mu \text { moles of trans cinnamic acic } \\
\left.\qquad \min ^{-1} \mathrm{~g}^{-1}\right)\end{array}$} \\
\hline & & 51 DAS & 53 DAS & 55 DAS \\
\hline $\mathbf{T 1}$ & Salicylic acid is sprayed at $1 \mathrm{mM}$ concentration at 50 DAS & 121 & 122 & 125 \\
\hline $\mathbf{T 2}$ & $\begin{array}{l}\text { Foliar spray of } 1 \mathrm{mM} \text { salicylic acid at } 50 \text { DAS followed by uredospores } \\
\text { suspension after } 2 \text { days }\end{array}$ & 124 & 127 & 130 \\
\hline T3 & Trichoderma viride $0.2 \%$ is sprayed at 50 DAS & 105 & 107 & 109 \\
\hline T4 & $\begin{array}{l}\text { Foliar spray of } 0.2 \% \text { Trichodermaviride spray at } 50 \text { DAS followed by } \\
\text { uredospores suspension after } 2 \text { days }\end{array}$ & 112 & 116 & 118 \\
\hline T5 & Pseudomonas fluorescence $0.1 \%$ is sprayed at 50 DAS & 95 & 96 & 97 \\
\hline T6 & $\begin{array}{l}\text { Foliar spray of } 0.1 \% \text { Pseudomonas fluorescence spray at } 50 \text { DAS } \\
\text { followed by uredospores suspension after } 2 \text { days }\end{array}$ & 98 & 99 & 101 \\
\hline T7 & Jasmonic acid $0.5 \mathrm{mM}$ spray at 50 DAS & 115 & 118 & 120 \\
\hline T8 & $\begin{array}{l}\text { Foliar spray of } 0.5 \mathrm{mM} \text { Jasmonic acid spray at } 50 \text { DAS followed by } \\
\text { uredospore suspension after } 2 \text { days }\end{array}$ & 118 & 121 & 124 \\
\hline T9 & Uredospore suspension sprayed at 50 DAS & 88 & 90 & 91 \\
\hline $\mathbf{T 1 0}$ & Control & 81 & 82 & 83 \\
\hline $\mathbf{F}$ & & $* *$ & $* *$ & $* *$ \\
\hline SEm \pm & & 0.8563 & 0.4944 & 0.4944 \\
\hline CD@1\% & & 3.4459 & 1.9895 & 1.9895 \\
\hline
\end{tabular}

DAS- Days After Sowing **- significant 
Table.3 Estimation of the $\beta 1,3$-glucanase activity in cowpea leaves due to different elicitors

\begin{tabular}{|c|c|c|c|c|}
\hline \multirow[t]{2}{*}{ Treatments } & \multirow[t]{2}{*}{ Treatment details } & \multicolumn{3}{|c|}{$\begin{array}{l}\beta 1,3 \text {-glucanase ( } \mu \text { g of glucanase released } g^{-1} \\
\text { fresh wt) }\end{array}$} \\
\hline & & 51 DAS & 53 DAS & 55 DAS \\
\hline T1 & Salicylic acid is sprayed at $1 \mathrm{mM}$ concentration at 50 DAS & 14 & 16 & 18 \\
\hline $\mathbf{T 2}$ & $\begin{array}{l}\text { Foliar spray of } 1 \mathrm{mM} \text { salicylic acid at } 50 \text { DAS followed by } \\
\text { uredospores suspension after } 2 \text { days }\end{array}$ & 17 & 20 & 23 \\
\hline T3 & Trichoderma viride $0.2 \%$ is sprayed at $50 \mathrm{DAS}$ & 9 & 9 & 10 \\
\hline T4 & $\begin{array}{l}\text { Foliar spray of } 0.2 \% \text { Trichodermaviride spray at } 50 \text { DAS } \\
\text { followed by uredospores suspension after } 2 \text { days }\end{array}$ & 10 & 12 & 14 \\
\hline T5 & Pseudomonas fluorescence $0.1 \%$ is sprayed at 50 DAS & 7 & 8 & 9 \\
\hline T6 & $\begin{array}{l}\text { Foliar spray of } 0.1 \% \text { Pseudomonas fluorescence spray at } 50 \text { DAS } \\
\text { followed by uredospores suspension after } 2 \text { days }\end{array}$ & 9 & 10 & 12 \\
\hline T7 & Jasmonic acid $0.5 \mathrm{mM}$ spray & 15 & 18 & 21 \\
\hline T8 & $\begin{array}{l}\text { Foliar spray of } 0.5 \mathrm{mM} \text { Jasmonic acid spray at } 50 \text { DAS } \\
\text { followed by uredospore suspension after } 2 \text { days }\end{array}$ & 20 & 24 & 27 \\
\hline T9 & Uredospore suspension sprayed at 50 DAS & 13 & 14 & 15 \\
\hline T10 & Control & 7 & 8 & 9 \\
\hline $\mathbf{F}$ & & $* *$ & $* *$ & $* *$ \\
\hline S.Em \pm & & 0.3496 & 0.3651 & 0.2108 \\
\hline CD@1\% & & 1.4068 & 1.4693 & 0.8483 \\
\hline
\end{tabular}


Plate.1 Experimental setup to identify effective elicitors against rust disease in C-152

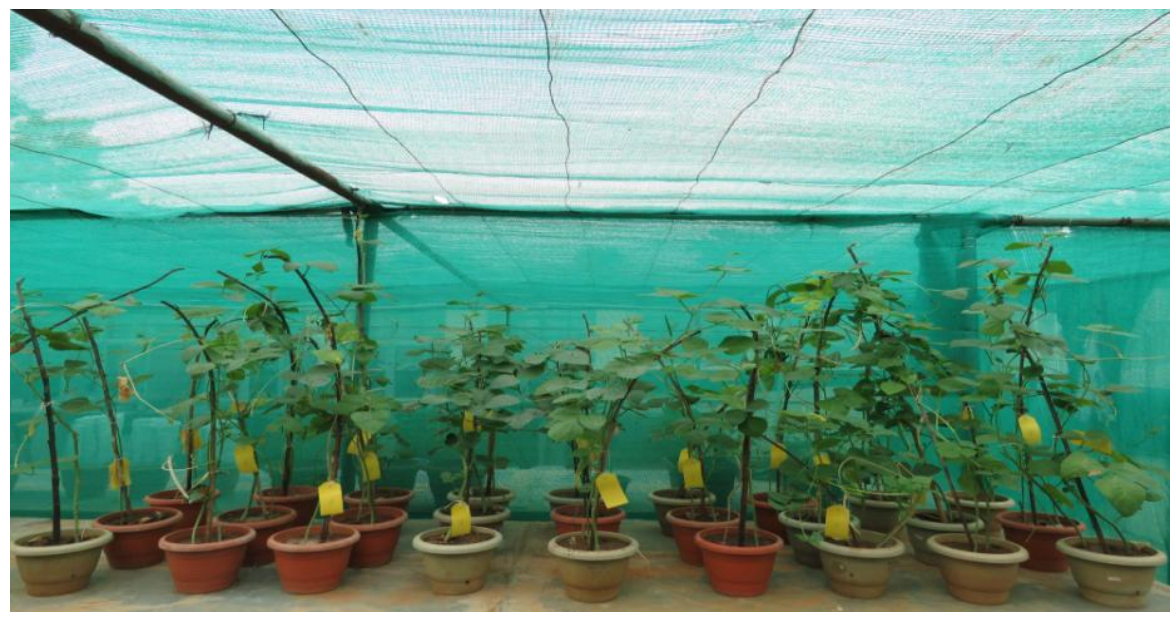

\section{及1,3-glucanase Activity}

Where $\beta 1,3$-glucanase enzyme activity was determined at 51, 53 and 55 DAS.

The results showed that at 51 DAS, the highest enzyme activity of 20 was recorded in T8 followed by $\mathrm{T} 2(17 \mu \mathrm{g}$ of glucanase released $\mathrm{g}^{-1}$ fresh wt.) and $\mathrm{T} 7(15 \mu \mathrm{g}$ of glucanase released $\mathrm{g}^{-1}$ fresh wt.) and there was a significant difference among them. Whereas, the lowest enzyme activity of $7 \mu \mathrm{g}$ of glucanase released $\mathrm{g}^{-1}$ fresh wt. was recorded in T10, followed by T5 (7 $\mu \mathrm{g}$ of glucanase released $\mathrm{g}^{-1}$ fresh wt.) and in T3 (9 $\mu \mathrm{g}$ of glucanase released $\mathrm{g}^{-1}$ fresh wt.) which were on par with each other.

At 53 DAS, the highest enzyme activity was recorded in T8 $(24 \mu \mathrm{g}$ of glucanase released $\mathrm{g}^{-1}$ fresh wt.) followed by T2 (20 $\mu \mathrm{g}$ of glucanase released $\mathrm{g}^{-1}$ fresh wt.) and T7 (18 $\mu \mathrm{g}$ of glucanase released $\mathrm{g}^{-1}$ fresh wt.) and there was a significant difference among them. The lowest enzyme activity was reported in T10 $(8 \mu \mathrm{g}$ of glucanase released $\mathrm{g}^{-1}$ fresh wt.) followed by T5 $(8 \mu \mathrm{g}$ of glucanase released $\mathrm{g}^{-1}$ fresh wt.) and in T3 (9 $\mu \mathrm{g}$ of glucanase released $\mathrm{g}^{-1}$ fresh wt.) and were on par with each other.
The highest enzyme activity of $27 \mu \mathrm{g}$ of glucanase released $\mathrm{g}^{-1}$ fresh wt. was recorded in T8 at 55 DAS followed by T2 $(23 \mu \mathrm{g}$ of glucanase released $\mathrm{g}^{-1}$ fresh wt.) and T7 (21 $\mu \mathrm{g}$ of glucanase released $\mathrm{g}^{-1}$ fresh wt.) and there was a significant difference among them. Whereas, the least enzyme activity was recorded in T10 $(9 \mu \mathrm{g}$ of glucanase released $\mathrm{g}^{-1}$ fresh wt.) followed by T5 $(9 \mu \mathrm{g}$ of glucanase released $\mathrm{g}^{-1}$ fresh wt.) and in T3 (10 $\mu \mathrm{g}$ of glucanase released $\mathrm{g}^{-1}$ fresh wt.) and were on par with each other.

The above findings revealed that there was increase in activity of $\beta 1,3$-glucanasein all treatments significantly over control. Further, highest enzymatic activity of 27 was observed with foliar spray of JA at $0.5 \mathrm{mM}$ followed by spraying of uredospore suspension after 2 days (T8) followed by foliar spray of $1 \mathrm{mM}$ salicylic acid followed by uredospore suspension after 2 days (T2) $23 \mu \mathrm{g}$ of glucanase released $\mathrm{g}^{-1}$ fresh wt which were significantly differ with each other.

The least enzyme activity of $9 \mu \mathrm{g}$ of glucanase released $\mathrm{g}^{-1}$ fresh wt. was recorded in control (T10) followed by $9 \mu \mathrm{g}$ of glucanase released $\mathrm{g}^{-1}$ fresh wt with foliar spray of $0.1 \%$ Pseudomonas fluorescence (T5), and $10 \mu \mathrm{g}$ of glucanase released $\mathrm{g}^{-1}$ 
fresh wt with foliar spray of $0.1 \%$ Trichoderma viridae (T3)and were on par with each other) (Table 3 ).

In the above results it was found that there was increase in the activity of enzymes and less pustules were observed as the days increases when we treated the plants with biotic and abiotic elicitors and the similar reports were observed by Sathyabama and Balasubramanian (1999) reported that pretreatment with SA reduced the number of rust pustules. PAL is the first enzyme of phenylpropanoid metabolism in higher plants and it has been suggested it plays a significant role in regulating the accumulation of phenolics, phytoalexins and lignins, the three key factors responsible for disease resistance (Vidhyasekaran 1988). In the present study ק1,3-glucanasewas higher in Pf1-treated plants challenge-inoculated with pathogen indicating that it might have resulted in the lysis of invading pathogen. Similar reports was found by Samia and Khallal (2007) where Peroxidase (POX), Polyphenols oxidase (PPO) and PAL significantly increased in tomato plants in response to Fusarium oxysporum. However, JA-treated plants (alone or combined with AM fungi) recorded the highest POX and PPX activities than the other infected plants. Similar results were investigated where in a higher peroxidase activity of 1.43 was observed in plants after application of $1 \mathrm{mM}$ SA followed by the inoculation of Alternaria alternata pathogen in peanut (Chitra et al., 2008).

\section{References}

Barclay, A., 1891, Additional urediniae from the neighbourhood of Simla. J. Asiatic Soc. Bengal,60: 211-230.

Betkas, Y. and Euglem, T., 2015, Synthetic plant defence elicitors. Front. Pl. Sci., 5(804): 1-17

Chitra, K., Ragupathi, N., Dhanalakshmi, K.,
Mareeshwari, P., Indra, N., Kamalakannan, A., Sankaralingam, A. and Rabindran, R., 2008, Salicylic acid induced systemic resistant on peanut against Alternaria alternate. Arch. Phytopathol. Pl. Prot., 41(1): 50-56.

Dixon, R. A., 2001, Natural Products and Plant Disease Resitance. Nature. 411: 843-847

Hartee, E. F., 1955. Modern Methods of Plant Analysis. (1st ed.). C.B.S. Publishers and Distributors. New Delhi. 106-116.

Joshi, J. R., Patel, V. M., Barad, H. L., Macwan, S. M. and Javid, E. 2018. Effect of land configuration and fertilizer management practices on growth, yield and yield attributes and economics of summer cowpea (Vigna unguiculata L.) under south Gujarat condition. Int. J. Curr. Microbiol. App. Sci., 7(1): 1148-1155.

Prabhamani, P. S. and Potdar, M. P, 2018, Response of cowpea (Vigna unguiculata L.) genotypes to sowing windows and planting geometry under Northern Transitional Zone of Karnataka. Int. J. Pure App. Biosci. 6(1): 820-827.

Rakshit, S, Mishra, S. K., Dasgupta, S. K. AND SHARMA, B., 2000, Dynamics of $\beta-1,3$ glucanase activity in powdery mildew resistant and susceptible lines of pea. J. Pl. Biochem. Biotech., 9(2): 9598.

Ross, W. W. and Senderoff, R. R., 1992, Phenylalanine ammonia lyase from loblolly pine; purification of the enzyme and isolation of the enzyme and isolation of complementary DNA clones. Pl. Physiol., 98: 380-386.

Samia, M. and El- Khallal, 2007, Induction and modulation of resistance in tomato plants against Fusarium wilt disease by bioagent fungi (Arbuscular mycorrhiza) and/or hormonal elicitors (Jasmonic acid \& Salicylic acid): 2-Changes in the antioxidant enzymes, phenolic 
compounds and pathogen relatedproteins, Australian J. Basic App. Sci., 1(4): 717-732.

Sathyabama, M. and Balasubramanian, R., 1999, Treatment of groundnut leaves with SA controls the development of rust disease caused by Puccinia arachidis Speg. 106: 166-173.

Singh, R. R. and Singh, M., 1997, Chemical control of pea rust. Ann. Pl. Prot. Sci. 5(1): 118-119.

Thakur, M. and Sohal, B. S., 2013 Role of elicitors in inducing resistance in plants against pathogen infection. Int. Scholarly Research Notices Biochemistry. 6: 1-10.

Verma A. K. and Deepthi, S., 2016 Abiotic stress and crop improvement: Current scenario. Advances in Plants and Agriculture Research. 4(4): 149-50.

Vidhyasekaran, P., 1988. Physiology of disease resistance in plants. Vol. I. Boca Raton, FL: CRC. Press. p 149.

\section{How to cite this article:}

Suryakanth, Venkatesh, N. S. Pankaja, N. Umashankar Kumar, J. Mahadeva and Sugeetha, G. 2020. Effect of Biotic and Abiotic Elicitors in Inducing Resistance against Cowpea Rust. Int.J.Curr.Microbiol.App.Sci. 9(11): 3573-3581. doi: https://doi.org/10.20546/ijcmas.2020.911.428 